49 Muehleck E. Letter to WWF Sheperd (Turner and Newall). 8 March, 1943. 50 Hardy HL. Personal communications, $1982,1989$.

51 Brown V. Letter to E Muehleck (Keasbey \& Mattison Co) and JFD Rohrbach (Raybestos-Manhattan). 22 October, 1948.

52 Brown V. Letter to sponsors (Amer Brake Shoe, Gatke Corp, Keasbey and Mattison, Raybestos-Manhattan Thermoid Corp, Union Asbestos and Rubber Co, Russell Manufacturing Co, United States Gypsum Co). 27 October 1948.

53 Brown V. Letter to WT Kelly (Amer Brake Shoe). 12 November, 1948.

54 Lanza AJ. Letter to AJ Vorwald. 14 December, 1948.

55 Vorwald AJ, Durkan TM, Pratt PC Experimental studies of asbestosis. Arch Ind Hyg Occup Med 1951;3: 1-43.

56 Brown V. Letter to sponsoring companies (see ref 54). 21 March, 1951.

57 Vorwald AJ. First interim report/asbestosis and pulmonary cancer (to Quebec Asbestos Mining Assn) Saranac Lake, NY: Saranac Laboratory, 7 May, 1952. Vorwald archives, Armed Forces Institute of Pathology, Washington, DC

58 Woodward JP (Johns-Manville). Minutes of discussions held at Saranac Lake on 7 November, 1950-14 November, 1950 . Vorwald archives.

59 For export only. Canadian Broadcasting Company; broadcast 4 October, 1988.

60 Kamal AAM, Sayed GM, Hassan MH, Massoud AA. Usage of personal protective devices among Egyptian industrial workers. Am J Ind Med 1988;13:707-16.

\section{Reply by Murray}

Sir,-Castleman chooses to criticise my account of the chronology of asbestos and its effects. I don't mind him doing this, for none of us is perfect. After all, I criticised his book, "Asbestos: Medical and Legal Aspects." Contrary to what he says, however, my review was not rejected for publication. It was never submitted. I was asked my opinion of the book by one of my colleagues in the London School of Hygiene and, having an unexpected weekend to spare, I read it and wrote what I thought. The book was published in 1986 and I wrote what I did in July 1988 so, even if I had wanted to, it was a bit late for a review.

To put the record straight and to let your readers determine whether it was "churlish" or not, this is what I wrote.

"Asbestos: Medical and Legal Aspects. Second Edition BI Castleman, Law and Business Inc 1986.

$\mathrm{Mr}$ Castleman does not like asbestos. $\mathrm{He}$ does not like the people who mine it, process it and adapt its products for sale. His dislike has grown into an obsession and his obsession into single issue fanaticism which closely resem- bles paranoia. In the fully developed form of this psychosis the individual adopts a false premise and then uses every device of selection and bias to support it. In the case of a person who thinks he is Napoleon or she is the Virgin Mary it is easy to recognise the false premise. It is less easy with a subject which has been ventilated in the media over the last 25 years to such an extent that the average man in the street tends to agree with the premise or something very like it - that asbestos has been an unmitigated disaster and that it should be banned.

In support of his hypothesis $\mathrm{Mr}$ Castleman has combed the world literature in a remarkable way. It is a pity that a book which has been so painstakingly researched should start with a false premise and arrive at entirely the wrong conclusions. It is characteristic of paranoia that the arguments are logical and well presented. It is the conclusion that is wrong, because it is arrived at in advance of the evidence and derives from emotion rather than scientific balanced appraisal.

The difficulty is that he is not entirely wrong. Asbestos is a dangerous material which has killed many people and will continue to do so, though less and less as our knowledge increases. Our main problem is that the effects of exposure are delayed up to 40 years, during which time our expectations are increasing and our diagnostic methods are improving so that we have to run fast to stay in the same place. Moreover, medicine has always had its priorities. Some subjects take the centre of the stage according to social demands of medical advances. What $\mathrm{Mr}$ Castleman does is to turn the spotlight, the blinding light of hindsight, on what was a very obscure problem and over illuminate it as though it had occupied centre stage for the greater part of this century.

At the very beginning he starts to bend the facts to suit his argument. Pliny did not recommend bladders as a protection against asbestos but against vermilion which caused acute mercury poisoning. It may be that some people in ancient times were affected by asbestos, just as our stone age ancestors may have been affected by silica from the manufacture or use of flint tools, but there is no evidence for $\mathrm{Mr}$ Castleman's comments about Roman slaves. None of the Greek or Roman physicians described the effects of asbestos, so that the statement that the disease was "discovered by the ancients," while adding historical colour and apparent verisimilitude, is manifest nonsense.

This temptation to dramatise and emotionalise is apparent throughout the whole book. I have not counted the emotional adjectives but the book is liberally besprinkled with them while the author flogs himself into a lather of indignation. One early example is a reference to the "devastating" pulmonary disease at the beginning of the century. There was such a disease, but it was called pulmonary tuberculosis and this was such an ever present disease that when Dr Murray discovered the first case of asbestosis in 1899 he did not publish it, even as a medical curiosity. He must have discussed it with his colleagues because he was invited to give evidence to the Department Committee on Compensation for Industrial Diseases in 1906 to which $\mathrm{Mr}$ Castleman makes reference.

At the beginning of the century there was a great deal of interest in industrial disease. The priorities were lead and mercury poisoning from which people were obviously dying, and phossy jaw, which destroyed the beauty of young women. The occupational chest diseases were so obscured by tuberculosis that the Departmental Committee of 1907 in the United Kingdom found itself unable to define these diseases adequately for compensation purposes even though the existence of potters rot, grinders asthma and ganister disease were well known. It was not until 1918 that the role of silica became manifest and this became the priority in research into occupational pulmonary disease to such an extent as to limit the study of asbestos because it was a silicate. This was true until the 1950 s when coal workers pneumoconiosis took over centre stage. Silica and coal dust are still as fibrogenic as they always were but $\mathrm{Mr}$ Castleman awards no medals to the medicine and hygiene professions for having controlled these problems.

Instead he concentrates single mindedly on his subject and accurately, for the most part, records the references to asbestosis in the medical literature. What he lacks is a broad view of the developing subject. He approaches his task with the enthusiasm and intolerance of the new convert who has discovered the secret of salvation. His 
enthusiasm betrays him on several occasions into telescoping time. For example he refers to Sir Thomas Legge, who had questioned Montague Murray in 1906, as soon afterwards lamenting, "looking back in the light of present knowledge it is impossible not to feel that opportunities for discovery and prevention were badly missed". Mr Castleman gives the date of that quotation as 1934 which is not exactly soon after 1906. Actually Sir Thomas Legge said it beforehand in 1928 which was sooner but not much. This is one of the few references which Mr Castleman does not have, but it illustrates the perils of hindsight. It is very easy to be wise. . . . even for such an expert as Sir Thomas. How much more so for the non-expert $\mathrm{Mr}$ Castleman.

It would be tedious to enumerate the many examples of selection, bias and emotionalism throughout the book. Even though he recognises that what is written does not suddenly become common knowledge ( $p$ 134) he continually makes the assumption that it does. He does not appreciate the gradual accretion of medical and hygiene knowledge, though at one point he recognises that scepticism is a tradition in science. He selects references which suit his arguments and ignores those that do not. $\mathrm{He}$ sneers at industrial doctors and hygienists, some of whom he names. He did not know any of them, individually or corporately, but he is liberal with his insults. He has his favourites and his "betes noires". Some people are favourites when he quotes them in favour of his arguments, but villains when they do not conform. He uses discredited information like the infamous Califano document, but not the more recent information by Doll. He praises the ILO for having raised the problem in the 1930s, but criticises it for its Code of Practice in 1984. He does not refer to Convention 162 and Recommendation 172 of 1986 . He might be forgiven for not having the final text of the Convention and Recommendation, but he ought to have known that an international instrument, debated by a tripartite body, was in prospect.

The most damning indictment of the fanaticism of the book is the absence of any reference to smoking. Cancer of the lung was a relatively rare disease until the epidemiological study of Sir Richard Doll in the United Kingdom in 1947. The evidence, even of his favourite Dr Selikoff, is that there is a synergistic action so far as bronchogenic carcinoma is concerned, between asbestos and smoking. Yet $\mathrm{Mr}$ Castleman does not mention it. $\mathrm{He}$ does not appear to recognise that there is no relation between mesothelioma and smoking because this too is not mentioned, probably because it might dilute his argument.

Perhaps the most ludicrous chapter is that concerning brake linings. First of all he confuses the manufacture of brake linings with their repair and maintenance. Of all the references he quotes there is only one which refers specifically to garage mechanics and even there the effects are speculative. He does not find it surprising that the millions of people who have been exposed to asbestos from brake linings since the beginning of the century have suffered rarely if at all from asbestos related disease.

He refers (p 611) to his own exposure and that of his younger sister and his mother; he does not say if his mother is dead and if she died of an asbestos-related disease. He admits (p 619) that some people die of causes unrelated to their asbestos exposure but he brings them in as well.

$\mathrm{He}$ does have the grace to publish the statement of Francis May at Appendix 2 pages $655-680$ without comment. In contrast to the rest of the book it is not a diatribe but a sober, competent, well balanced statement about the background of asbestos related disease and the responsibility of employers."

\section{Dr Robert Murray}

\subsubsection{8}

I see no reason to change my opinion, and his letter to you, containing more references than my article, is further evidence of his paranoia about asbestos. I paid tribute, in my review, albeit left handedly, to his delving into past publications and I accept, as I said in my article, that there were indications from German and Czech papers about lung cancer in relation to asbestosis. I said that it was these that had alerted my old chief, Merewether, and given rise to the investigation of 1947 which was not published until 1949. But these were anecdotes, numerators without denominators, and not a basis for action. Even in the light of his discoveries, Merewether did not conduct a campaign against the asbestos industry in the United Kingdon. He believed, as he persuaded me to believe, that the duty of a doctor in industry, as I said in my article, was to point out the potential dangers.

So, if he wants to accuse me, unjustly, of not recognising that there were some articles on asbestos and lung cancer before the war, I accuse him, justly, of drawing the long bow about cases in ancient times. Kevin Browne and $I$ have made it clear that there were no references to asbestos related disease in ancient times.' There has been no riposte about this. Let him produce the evidence. In any case, do you listen to every oracular statement about every disease? If ever $\mathrm{Alz}$ heimer's disease is associated with aluminium, all the Cassandras of the world will jump up and down like Castleman and say, "I told you so".

But I was there at the time, which Castleman was not, and the main problems, so far as cancer was concerned, were the bladder cancers in the chemical industry and skin cancer in the cotton industry, both of which have been brought under control. (We did some things right in the 1940 s and $50 \mathrm{~s}$, though it has taken until now to appreciate it.) Lung cancer was a rare disease outside smoking. Even Doll, when he did his study, published in 1955, thought that the controls introduced by the 1931 regulations (the first regulations in any country to tackle the problem of asbestos) would prevent future cases of lung cancer. Dust problems in the 1950s were primarily those of coal miners. Maybe this was because of the small numbers in the asbestos using industries, but there have to be priorities when resources are scarce, as they undoubtedly were. How long did it take the United States Surgeon General to accept the evidence about smoking? And how long did it take the United States to accept the evidence about coal workers' pneumoconiosis?

There can be no doubt that 1960 was the Rubicon so far as asbestos and cancer were concerned. Not even Castleman can assert that mesothelioma was known to be associated with asbestos before 1960, even though Merewether had referred to lung and pleural cancer. I remember having seen a mesothelioma in about 1950 in the postmortem room of the hospital in Bury, Lancashire. I had never seen such a white cuirass of a tumour, but the Home Office pathologist who was doing the postmortem examination said, "Asbestos", as though he had seen it before. I was too young and 
inexperienced to insist on further histology and so I lost my opportunity of fame, as he and doubtless many others did too.

We were interested in occupational cancer and we, too, had read Hueper, who, according to Merewether, was a cancerphile. I never met him, but he was obviously a very nice man. If you fire off in every direction, you are bound to hit something some time, as he did. We had a job to do and we couldn't afford to use our limited resources in following up all Hueper's claims.

It was for this reason that I wrote in my reply to Huncharek, that the reaction of the asbestos industry was not as reprehensible as has been made out by Castleman and Brodeur. This seems to have raised the hackles of Castleman. But I ask him, if we were not sure that asbestos was a carcinogen (and by "we" I modestly include Merewether and Doll), why should industry assume the responsibility? And I ask again as I did in my reply to Huncharek, what was the American government doing? Did they shuffle off their responsibilities on to the states? And what were the unions doing? Where were the great champions of workers' rights? When the American government admits that it recommended, for perfectly legitimate reasons, the use of asbestos in navy and merchant ships, then I will listen to complaints against employers. The US Department of Health, Education, and Welfare knew as much as anybody about the dangers of asbestos, but there is no evidence of them having recommended any restrictions on its use.

I am no expert in animal studies, but I have the greatest reservations in extrapolating animal results to man.
Once again, it is a cause for suspicion, but not for precipitate action. So I do not roundly condemn the asbestos industry for what they did, or did not, do. After all, the industry in the United Kingdom established the Asbestosis Research Council, which has probably done more to reveal the problems of asbestos than any other body.

Every good Victorian novel had its death bed scene and Castleman's description of the death of Tony Lanza, via Harriet Hardy, is no exception. Who among us, with hindsight, does not have regrets about his sins of omission or commission?

So, Castleman, criticise if you like, but have the grace to admit that other people have the right to criticise your criticisms.

1 Brown K, Murray R. Asbestos and the Romans. Lancet 1990;336:445.

\section{NOTICE}

Spirometry: Pulmonary Function Testing in Occupational Health (NIOSH Course 097) 1991 Long Beach, California, USA, 1011 October 1991.

This workshop will provide instruction in all aspects of spirometry through lectures, practicums, and testing. Training is intended for occupational health nurses, physicians, technicians, industrial hygienists, and others responsible for performing accurace pulmonary func- tion testing of employees. This $\mathrm{NIOSH}$-approved workshop has been developed according to American Thoracic Society standards for pulmonary function testing. As a result of attending these workshops, you should be able to:

Describe the value of spirometry testing in clinic and work settings

Describe and instruct on the basic anatomy and physiology relevant to spirometry

Perform tests and interpret results

Calculate correctly FVC, FEV $_{1}$, $\mathrm{FEF}_{25-75 \%}, \mathrm{FEV}_{1}$, and predicted normals

The programme is under the direction of John Howard, MD, MPH, Assistant Professor and Acting Director of the Occupational Medicine Residency Training Programme at University of California College of Medicine, Irvine. Dr Howard has conducted similar workshops for the University of California, Irvine, for several years. This programme has been approved by the California Board of Registered Nursing, BRN Provider No. 07784 for 15 hours. In addition, MBA Inc offers 1.5 continuing education units for successful completion of each workshop. Approval is pending from the American Board of Industrial Hygiene for CM points. Course hours are 8:00-5:00 daily. The tuition fee of $\$ 375.00$ includes refreshments and instructional materials. Enrolment is limited to 25 . The fee, less a 20 per cent administration charge, is refundable if written cancellation is received two weeks prior to the programme date. For further information contact: McIntyre, Birkner, and Associates, 5865 Dovetail Drive, Agoura Hills, California 91301, UA. 